\title{
SEX EDUCATION IN THE CONTEXT OF INDONESIAN EARLY CHILDHOOD
}

\author{
Daviq Chairilsyah \\ ( daviqch@yahoo.com ) \\ Teacher Education of Early Childhood Education, FKIP Universitas Riau, \\ Indonesia
}

\begin{abstract}
Indonesia is a country that is experiencing a crisis of child abuse and sexual violence. Data from 2015 to 2019 shows a significant increase in this problem. KPAI data states that the culprit is the closest person to the child such as stepfather and biological, closest family, and colleague. When our children ask about their sexuality, we will be moved quickly. This attitudes like that mean wrong, because children have a curiosity about many things, if we as parents cannot direct properly, cannot provide clear information they tend to look for information from others and their friends, the information is not necessarily good. Very few people, especially parents who care about sex education and place sex as something important. Even many parents who do not provide sex education to children, with the reason the child will know it by itself. During this time, the idea of sex is belonging to adults only, so discussing the problem of sex in children is not easy. However, teaching sex education to children must be given so that children do not go wrong in their lives. The purpose of sex education in early childhood is to provide an adequate understanding of physical, mental, and emotional maturity processes, reducing fear and anxiety related to sexual adjustment and development. Sex education is given starting from the age of five, age 1-5 years, age 5-10 years, age before adolescence, adolescence. How to educate young children about sex through family, environment, and education at school.
\end{abstract}

Keywords: early childhood, sex education.

\section{INTRODUCTION}

Indonesia is a state of crisis in many aspects of life including in sexual issues. As revealed by Jawa pos.com, the last three years seem to be the most alarming year for the world of Indonesian children. The Indonesian Children Protection Commission (KPAI) found hundreds of cases of sexual violence against children allegedly committed by the closest people as perpetrators. KPAI revealed the data showed that it found 218 cases of child sexual violence in 2015. While in 2016 and 2017, KPAI noted there were 120 cases and 116 cases of sexual violence against children respectively. While in 2018 and 2019, KPAI noted there were 206 cases and 78 cases until now. 
In the KPAI data, the culprit is the closest person to the child, such as stepfather and biological father, closest family, and friends. KPAI has also provided references and recommendations on care and long-term solutions related to these cases. Therefore, KPAI asks anyone to report cases of sexual violence against children to the authorities to get legal treatment. Besides, KPAI also continues to encourage the government and collaborate with the Ministry of Health, BKKBN, the police, and local governments about the responsibility of protecting children.

Sex education is a way of teaching or education that can help children to overcome problems that originate from the sexual drive. Thus this sex education aims to explain all matters relating to sex and sexuality in a reasonable form. In this case, sex education should be given first by parents, but not all parents want to be open to children in discussing sexual problems. Different socioeconomic levels and educational levels cause some parents are willing and able to provide information about sex but more are unable and understand the problem (Ulwan, 2016).

Good sex education must be complemented by ethics education, education about relationships between human beings both in family relationships and in society. The purpose of sex education is not to arouse curiosity and desire to try sexual relations between adolescents, but want to prepare young people to know about sexuality and its consequences if done without obeying the rule of law, religion, and customs as well as the mental and material readiness of a person (Djiwandono, 2001).

According to Fahmi (2016) surveyed by WHO about sex education proves that sex education can reduce or prevent careless sexual behaviour which also means reducing the spread of disease due to free sex. Proper sex education must include elements of human rights, as well as cultural and religious values included in it so that it will be a moral and moral education as well. Sex education in Indonesia is still a controversy, there are still many members of the community who have not agreed to sex education at home or school. The impact can be everywhere, among others, in choosing the spectacle of western culture depicted in films or videos often showing free sex life among adolescents, it is not solely due to addiction but arises because of the perception that sexual intercourse is already an ordinary thing. Therefore sex education should be an important part of education in schools.

In the book entitled 'Bunda, Apa itu Sex/ Mother, What is Sex', when we hear the word sex what comes to our minds is pornographic, vulgar, disgusting and others. Compulsory sex education is given by parents to their children as early as possible. Precisely starts at an early age, because at this age children can do two-way communication and can understand about their organs and can also continue the introduction of internal organs. Sex education for early childhood is different from sex education for teenagers. Sex education for adolescents is more about the biological description of sex and reproductive organs, relationship problems, sexuality, reproductive health, and sexually transmitted diseases, while in early childhood is more about the recognition of the role of sex and simple anatomy. 
Children are an investment in the nation's future. Therefore, the responsibility of parents and educators must strive for children's optimal growth and development in line with expectations. The child should be kept nurtured, guided, and protected to be healthy and prosperous both physically, emotionally, intellectually, socially, and sexually. Parents' responsibilities do not only cover or are limited to material needs but include all aspects of their children's lives, including sex education. Understanding and choosing the right method of sex education will lead the child to be a person who can protect himself from prohibited acts and be aware of threats and warnings from immoral acts and have a clear religious grip (Nugraha, 2014).

At the meeting of the World Education Delegation in New York in 2002, the World Fit for Children Declaration had four issues that were of particular concern in the declaration. The third point among them is mentioned protecting against abuse, exploitation, and violence. This declaration was issued as an effort to keep children away from anything that could disrupt their physical, psychological and social conditions. But the reality that is happening right now still shows that the condition of the children's world is far from what is expected.

Sari (2012) revealed several causes that make children easily subjected to child sexual abuse, namely innocent children who trust all adults, young children who are unable to detect the motivation possessed by adults, children are taught to obey adults, naturally children have a curiosity about their bodies and children are alienated from information relating to their sexuality. Therefore, children have a variety of characters that can plunge them into victims of child sexual abuse, children need protection from adults, especially their parents.

This sex incident did not only occur in one kindergarten, quoted from various media such as SINDOnews, Liputan6.com, Riau Pos, Detik.com, Tribun.com, and other electronic media reported that sexual violence against children occurred almost every day. Sexual violence in children is very influential in the development of children such as children's mentality. Depression experienced by children becomes difficult to forget.

From a psychological standpoint, children sexual violence can cause long- term or short -term harm, including psychological disorders in the future. The effects of sexual violence in psychological, emotional, physical and social forms include depression, trauma, anxiety, eating disorders, feelings of inferiority, shutting down from relationships, and much more. For the long-term, victims of abuse may become perpetrators as adults. Various studies have shown a correlation between past bad experiences with sexual crimes committed by someone when they reach adulthood (Suryabrata, 2010).

In physical terms, sexual harassment can have severe consequences such as bleeding which in cases can also cause death. Besides, sexually transmitted diseases can be transmitted by abusers. Factors causing sexual violence are hormonal disorders, the influence of genetic predisposition to sexual deviations, environmental factors, material 
factors, and climate. The above factors are usually triggered by the environment, family, and education, so that's why sex education at an early age is needed.

\section{SEX EDUCATION}

\section{Definition of Sex Education}

Sex education is the delivery of information through the introduction (names and functions) of limbs, understanding gender differences, describing sexual behaviour (relationships and intimacy), as well as knowledge of values and norms that exist in society related to gender. Sex education also teaches how to build attitudes (Madani, 2014).

Sutiretna defines sex education as an effort to provide education and knowledge about biological, psychological, and psycho-social changes as a result of human growth and development. In other words, sex education is an effort to give knowledge about the function of reproductive organs and instill moral-ethical values and religious commitments so that there is no abuse of the reproductive organs (Nawati, 2013).

Concerning religious values, Abdullah Nashih Ulwan defines sex education as an effort to teach, raise awareness and enlightenment about sexual problems given to children since he understands issues relating to sex, conscience, and marriage. By then, if the child has grown up, he will know the problems that are permitted and forbidden, even able to apply behaviour by his religion and will not fulfill his sexual conscience in a way that is not permitted by his religion (Nawati, 2013).

In the perspective of psychology, Zainuddin Mutadin wrote in one of the psychology websites that sex education is a way of teaching or education that can help young people to deal with life problems that are based on sexual drive. Thus, sex education is intended to apply all things related to sex and sexuality in a fair form (Nawati, 2013).

Meanwhile, Sarlito, in one of his books assessed that sex education is clear and true information about human sexuality issues, which includes the process of conception, pregnancy to birth, sexual behaviour, sexual relations, and aspects health, psychiatric, and social. The problem of sex education that is given is duly related to the norms prevailing in society, what is prohibited, what is permitted, and how to do it without violating the rules that apply in the community (Chomaria, 2014).

So, sex education is the instruction of issues relating to human sexuality, including emotional relations and responsibilities, human sexual anatomy, sexual activity, sexual reproduction and age of consent. Common avenues for sex education are parents or caregivers, formal school programs, and public health campaigns (Chairilsyah, 2019). 


\section{The Purpose of Sex Education}

Sex education does not always talk about genitals or intercourse. Madani (2003) emphasized that in addition to applying anatomical and biological aspects, sexual education also applied psychological and moral aspects. Proper sex education must include elements of human rights as well as cultural and religious values. Thus, sex education can also be regarded as moral education and moral.

Kartono Mohamad in the panel discussion of Islam and sex education for adolescents explained that good sex education had the purpose of fostering the family and must make parents responsible. In line with Kartono, Torto Husodo said that good sex education must be complemented by ethics education, education about relationships between humans, both in relationships within the family and society.

Furthermore, Madani (2014) breaks down the goals of sex education into eight points, as follows: 1) Provide an adequate understanding of the physical, mental, and emotional maturity processes associated with sexual problems in adolescents. 2) Reducing fear and anxiety related to development and adjustment concerning sexual development and adjustment (roles, demands, and responsibilities). 3) Form attitudes and provide knowledge about sex in all its various manifestations. 4) Give the understanding that the relationship between humans can bring satisfaction to both individuals and family life. 5) Provide an understanding of the need for essential moral values to provide a basis for making decisions relating to sexual behaviour. 6) Provide knowledge about sexual misconduct and irregularities so that individuals can protect and fight exploitation which can interfere with physical and mental health. 7) Provide understanding and conditions that can make individuals carry out sexual activities effectively and in a variety of roles, such as wives and husbands, parents, and members of the community.

So, the goal of sex education is to form a healthy emotional attitude towards sexual problems and guide children and adolescents towards healthy and responsible adult life. This is intended so that they do not consider sex as something disgusting and dirty. However, more as a human innate, which is a gift of God and function is important for the continuity of human life.

In a psychology consulting service site (episentrum.com) states there are at least five goals that can be achieved by parents or the benefits that can be felt by children regarding sex education (Nawati, 2013). These benefits include the following: 1) Children understand the role of sex. By providing sexuality education to children, a boy is expected to grow and develop into a complete man. Likewise with women who are expected to grow and develop into full-fledged women so that no one feels uncomfortable with the gender roles they have. 2) Receive any physical changes that are experienced naturally and as is. Childhood is a time when a human being is undergoing change and development, both physically and psychologically. Especially when they enter puberty, where physical and psychological changes experience the most rapid stages compared to the period before and after. 3) Remove unhealthy curiosity. Preferably, those who are closest such as parents and teachers become fun figures for 
children to fulfill their curiosity about many things, including about sexuality. This is intended so that children do not focus children find out answers to questions through friends, comics, VCD/DVD, or other media that does not guarantee the child gets the correct information.

The purpose of early sex education is explained in a book written in early sex education writing the formulator of Islamic law and scientists agree on the importance of educating children before the age of puberty by providing the basis of sexual knowledge and its fiqh laws (Madani, 2014). Sex education is given when a child starts to recognize his limbs, at the time sex education is needed. According to Singgih D. Gunarso in the book Practical Psychology, Children, Adolescents, and Families, conveying this sex education material should be given early when the child has begun to ask about sex differences between himself and others. Do it continuously and gradually, adapted to the needs and elements of the child and the child's catch (Nawati, 2013). A source (collection.info) divides the stages of sex education by age group:

1. Toddler, ages 1-5 Years.

At this age, you can start to instill sex education. The way is easy, by assessing introducing your baby's sex organs briefly. No need to give a detailed explanation because the attention span of a child is usually short. For example, when bathing the child, parents can help explain their genitals briefly.

2. Age 5-10 years

At this age, children usually start actively asking about sex. For example, the child will ask where he is from, or general questions, such as the origin of the baby, usually frank answers will be effective.

3. The Age Towards Teenagers

As the child develops, it is time for you to explain menstruation, wet dreams, and also the physical changes that occur in a teenager. You can explain that the little girl will experience changes in breast shape, and explain the hairs around the genitals.

4. Teenage Ages

At this time, a teenager will experience many changes sexually. Parents need to intensively plant good moral values to them. Explain the disadvantages of free sex, for example, transmitted diseases and their emotional consequences. According to research, early sex education will prevent pregnancy outside marriage when children grow into adolescence and adulthood.

\section{How to Educate Sex Education to Early Childhood?}

According to Madani (2014) in his book entitled Early Sex Education for Muslim Children explains several ways of educating sex education in early childhood as follows:

1. Sex Education and Jurisprudence in Children.

Since starting to be able to think and be able to distinguish between good and bad, children need to be given knowledge about sex according to their age and be taught the laws of fiqh little by little, especially the ethics of sex education that they need. The task of education is to practice it practically to understand these 
laws by familiarizing them with daily activities and observing the extent ofchildren's success in applying them. Not only knowing how children store their knowledge but must be able to apply it.

2. Asking for permission.

Always teach ethics to ask permission from early childhood in all matters, bearing in mind that this is a prelude to the rules of decency.

3. Keeping the child away from sexual activity.

The view of many educators is related to the importance of keeping early childhood away from seeing sexual activity between husband and wife because ofthe great danger to honesty in the future. Therefore sexual activity must be kept out of the reach of children, especially early childhood.

4. Separating Children's Beds.

Separating a child's bed is another educational method for the cleanliness of our sex education for children. Through this separation, the child is far from the parents' room. Bed separation is an educational method in every family.

According to Muslik Nawati's (2013) book entitled 'Bunda, Seks itu apa?/ Mother, What is Sex?' explains how to educate sex education in early childhood as follows:

1. Parents must understand the real meaning of sex.

Early childhood is a child who often asks, so as a good parent will always answer the questions posed clearly and correctly. Many parents who consider sex education is a taboo education and education that violates the norms that are in religion, therefore as parents must have the knowledge and understand sex in early childhood education so that children do not seek answers in places that are not supposed to.

2. Mastering Communication Technique with Children

Never even once underestimate the problems of children, especially those related to sex. Once a parent is incorrect and improperly explains it, then the child will perceive the sexual problems they are asking about. However, parents should not avoid this responsibility. Let's face it, what is needed is a technique to communicate with children properly and correctly.

In communicating with children, we need to pay attention to various aspects, including the age of child development, methods of communicating with children, and the stages or steps in communicating, so that children can get good information and correct. Communicating with children is important in maintaining relationships with them. Through this communication, parents can easily extract various information owned by children and can then be used as a reference to provide answers or questions to children. The techniques for communicating with children can be done in the following ways:

1. Telling stories.

Through this story, the message conveyed to the child can be easily received, remembering the child loves to tell stories. However, the story conveyed should be following the message to be conveyed.

2. Facilitating.

Facilitating children is part of how to communicate. In this way, the child's expression or response to the message received. In facilitating, we must be able to 
express feelings and not be dominant. The child must be given a response to the message conveyed through listening attentively and do not show the bad message to the child.

3. Drawing.

Like writing, drawing can be used to express a child's expression, such as feelings of annoyance and anger. After finishing drawing ask the purpose of the picture to the child.

4. Playing.

Playing is the most effective means of helping to communicate with children. Through this activity, interpersonal relationships between children and parents can be established with certain messages that can be easily conveyed.

Sex is the most misinterpreted thing in society, education, even family. At present, there are many mistakes in thinking about the application of sex in early childhood, including 1) Sex is just an introduction to adults in people who are married, things like this that make many teenagers who have unhealthy sex. 2) Mythology explains that if sexual learning encourages students to become sexually active. 3) Many people think that if sexual learning will lead to pregnancy in adolescents. 4) Sex education is only explained at school. 5) Old people rarely want to interfere with the development of sex in early childhood. 6) Too focused on the problem of the function of the reproductive organs until parents, educators, and the environment assume that sex education is not a good thing. 7) Once an explanation is considered sufficient, this is the explanation we know. Parents assume young children should not know much in understanding sex. 8) The contents are only about virginity, and sin. Parents assume education about sex is education that violates the prevailing religion and norms. 9) Not given a place to complain and to raise questions. If the child does not have friends then the child is looking for someone else who is not supposed to be the place to ask so the child will get the wrong explanation.

\section{ROLE OF PARENTS, SCHOOLS, AND ENVIRONMENT IN CHILDREN'S SEX EDUCATION}

Life is never separated from parents, schools and the environment. These three factors play an important role in the spread of large and mutually sustainable influence. Sex education at an early age is the role of all people and the environment. The role of parents, school, and environment is equally important in the sexual development of children (Al Madani, 2004).

1. Sex Education in the Educational Environment

Sex education in early childhood is as follows:

a. The needs of toddlers which mainly revolve around the physical needs and psychological needs, such as receiving affection, feeling safe and protected. Children who feel compassion, safe and comfortable will make children avoid sexual violence.

b. Early childhood educators must establish communicative relationships verbally, emotionally, and in good relationships with family members to get the concept 
of children. Communication and approach with parents is a good way of sex education because the teacher will get the habits of children and families.

c. Establish guidance which is mainly used in group fields. The formation of this field is the formation of formal guidance between parents and early childhood.

d. Teacher consulting services with parents are prioritized in overcoming annoying problems.

2. Sex Education in the Family Environment

The family is the first and foremost environment for children. The family environment is an environment that instills the basic values of religion, morals, discipline, and social in children. Here's how to introduce sex education to young children through the family:

a. Through Aqiqah

Aqiqah is a process of giving names which for men slaughter two goats and one goat woman, this aqiqah process is the order of the Prophet Muhammad. Aqiqah serves to inform others about the sex of a child.

b. Give a good name

Giving a good name will give birth to a good soul.

c. Through circumcision

Circumcision is cutting the skin at the tip of the male genitals. This circumcision aims to keep the genitals clean and maintain them well and keep away from things that are not good.

d. Familiarize children gathering in one family

The gathering is a must for every family member. Because by gathering together we will solve problems and tie the rope together.

e. Through Bathing Children

Bathing is a requirement of the human body. Bathing is an activity to give and nourish the body from all impurities and germs that stick to the body. Bathing is done twice a day, morning and evening. Bathing can be used as a method to introduce sex education, bathing is very effective at introducing all members of the body.

f. Separate Children's Beds

Separating a child's bed in an attempt to teach children how to give responsibilities to themselves personally such as bathing themselves.

3. Sex Education in the Association of Children

The environment is the scope of a very large child. Nearly half of the children's activities are environment, both play environment, social environment, and much more that can be done in the environment. Formation of the character of children mostly occurs within the scope of the environment in which they live, a good association for children is a clean and comfortable environment, but a comfortable environment is not impossible for sexual violence against young children to occur. We as an environment of early childhood must educate them as well and properly as paying attention to early childhood in its development because in the environment not parents pay attention but we as people in their environment. The environment is the biggest place of violence against children, so parents and the environment must work together and help each other. 


\section{CONCLUSION}

Sex education is the delivery of information about the introduction of limbs, understanding gender differences, the elaboration of sexual behaviour, and the introduction of values and norms that exist in society related to gender. The purpose of sex education in early childhood is to provide an adequate understanding of physical, mental, and emotional maturity processes, reduce fear and anxiety associated with sexual adjustment and development, provide knowledge about sexual errors and deviations, so that children understand and understand the role of types genitals, accepting any physical changes that are experienced naturally and as they are, removing the less healthy curiosity, strengthen self-confidence and responsibility for himself.

Sex education is given starting from the age of five, age 1-5 years, age 5-10 years, age before adolescence, adolescence. How to educate early childhood about sex in the family, environment, and education is to educate sex by asking permission, away from children from sexual activity, separating the child's bed, parents must know about sex, and parents must be able to master how to communicate with children.

Based on the analysis in the discussion of this paper, the authors provide advice as an effort to explain about sex education in early childhood. Sexual learning and introduction are given to young children starting from the explanation of parents in the family and then assisted by kindergarten teachers so that children know what and why the importance of sexual recognition at an early age because so as not to be mistaken about sexual understanding. Early childhood has a very big curiosity about sex so we as parents and teachers must explain it thoroughly in simple language.

\section{REFERENCES}

Al Madani, Hilman. (2004). Mengapa Anak Kita Perlu Pendidikan Seksualitas? Cet. I. Jakarta: HAD Publikasi.

Chomaria, Nurul. (2014). Pendidikan Seks Untuk Anak. Jawa Tengah: Aqwa Medika.

Djiwandono, Sri Esti Wuryani. (2001). Menjawab Pertanyaan-pertanyaan Anak Anda Tentang Seks. Jakarta: Grasindo.

Fahmi. (2016). Early Childhood Sex Education in the Family Environment: The Qathruna Journal. Vol 3 (2), 69-97.

Madani, Yusuf. (2003). Pendidikan Seks Untuk Anak Dalam Islam. Cet. I. Jakarta: Pustaka Azzahra.

Madani, Yousef. (2014). Pendidikan Seks Usia Dini Bagi Anak Muslim. Jakarta: Pustaka Iltizam. 
Nawati, Muslik. (2013). Mother, What is Sex? Bandung: Yrama Widya.

Nugraha, Boyke, Dian. (2014). Early Childhood Sex Education for Muslim Children. Jakarta: Zahra Publishing House.

Sari, Dian Juni Eka. (2012). Relationship of Sex Education in the Family with Sexual Behavior: Journal of Public Health STIKes Prima Nusantara Bukittinggi. Vol 3 (2), 27-31.

Suryabrata, Sumadi. (2010). Educational Psychology . Jakarta: Rajawali Press.

Ulwan, Abdullah Nasih. (2016). Pendidikan Seks Untuk Anak Ala Nabi. Jakarta: Pustaka Iltizam. 